\title{
DEVELOPMENT AND VALIDATION OF A SOLID-PHASE EXTRACTION GAS CHROMATOGRAPHY-MASS SPECTROMETRY METHOD FOR THE SIMULTANEOUS QUANTIFICATION OF OPIOID DRUGS IN HUMAN WHOLE BLOOD AND PLASMA
}

\author{
FELIPE BRAVO ${ }^{1,2,3}$, DIEGO GONZALEZ ${ }^{1}$ and JULIO BENITES ${ }^{1,3 *}$ \\ ${ }^{I}$ Departamento de Ciencias Químicas y Farmacéuticas, Universidad Arturo Prat, Casilla 121, Iquique, Chile. \\ ${ }^{2}$ Laboratorio Referencial Norte. Servicio Médico Legal. Iquique, Chile. \\ ${ }^{3}$ Instituto de EtnoFarmacología (IDE), Universidad Arturo Prat. Iquique. Chile. Avenida Arturo Prat 2120. Casilla 121. Iquique. Chile.
}

(Received: March 8, 2011 - Accepted: June 9, 2011)

\begin{abstract}
A rapid, selective, sensitive, and specific method is presented to simultaneously quantify morphine, 6-monoacetylmorphine (6-MAM), codeine, heroin, fentanyl, and methadone in human whole blood and plasma. The drugs were extracted with phosphate buffer at pH 6, followed by solid-phase extraction (SPE) and quantification by GC/MS with electron impact ionization using helium as carrier gas. Quantification was performed based on nalorphine as internal standard (IS). The specificity, linearity, intra- and inter-assay precision and accuracy, and extraction recovery were fully evaluated. The limits of detection (LODs) were $0.40-7.63 \mathrm{ng} / \mathrm{mL}$ for whole blood and $0.80-32.00 \mathrm{ng} / \mathrm{mL}$ for plasma. The method is fast, simple, and accurate, with the sensitivity and specificity required in forensic and clinical toxicology.
\end{abstract}

Keywords: Opiods, gas chromatography, mass selective detector, solid-phase extraction

\section{INTRODUCTION}

Abuse of illicit drugs has incalculable societal consequences, such as treatment costs, higher incidence of criminality, and economic damage. ${ }^{1}$ Several studies have shown that, in general, illicit substance use disorders are associated with excess mortality. ${ }^{2}$

The prevalence of opioids use and abuse has been increasing substantially in our society. Worldwide, more than 15 million people consume illicit opioids, ${ }^{3}$ and their use has caused significant personal and public health problems in many countries across the globe. ${ }^{4}$ This elevated risk is concentrated across several causes of death: accidental drug overdose, suicide, trauma (e.g. motor vehicle accidents, homicide, or other injuries), and HIV (in countries where HIV is prevalent among people who inject drugs). ${ }^{5,6}$

Opioids are a drug family having morphine-like effects. Their main medical use is to relieve acute and chronic pain, e.g., in the treatment of cancer patients and postoperatively. ${ }^{7,8}$ The use of the opioid alkaloids can be accompanied by significant adverse effects, including respiratory depression, nausea, vomiting, pruritus, and neuroexcitation. Use of these agents are also associated with mood elevation, tolerance, and dependence. ${ }^{9,10}$

Screening for opioids are commonly performed by immunoassays, followed by confirmation by gas chromatography-mass spectrometry. However, no immunoassay covers all opioid drugs. ${ }^{11}$ Several analytical methods for the detection of multiple opiod drugs in different biological matrices such as whole blood, ${ }^{11}$ oral fluids, ${ }^{12}$ urine,${ }^{13}$ meconium, ${ }^{14,15}$ plasma, ${ }^{16}$ hair, $, 7,18$ skin, ${ }^{19}$ sweat,${ }^{20}$ and placenta ${ }^{21}$ have been reported using LC-MS/MS, LC/MS, GC/MS, UPLCMS/MS, and LC-APCI-MS/MS.

In the north of Chile, we continue to broaden interest in the development and validation of chromatographic methods in drug abuse. ${ }^{22}$ The aim of this study was, therefore, to develop a rapid, selective, sensitive, and specific method to simultaneously quantify 6-MAM, morphine, codeine, fentanyl, heroin, and methadone in human whole blood and plasma by GC/MS, which is shown to be a powerful tool in the analysis of forensic and clinical toxicological cases.

\section{MATERIALS AND METHODS}

\section{Chemicals and reagents}

Morphine, 6-MAM, codeine, heroin, fentanyl, methadone, and nalorphine were purchased from Cerilliant (TX, USA). Ethyl acetate (HPLC grade) was purchased from Fisher (USA). Acetic acid, ammonia, potassium hydroxide, and potassium dihydrogen phosphate (analytical reagent grade) were purchased from Merck (Germany). Methanol and dichloromethane (HPLC grade) were purchased from Sigma-Aldrich (USA). N,O-Bis(trimethylsilyl)trifluoroacetam ide:trimethylchlorosilane was purchase from Supelco (USA).
Biological samples

Samples of outdated whole blood and plasma were obtained from the blood bank of "Dr. Ernesto Torres Galdames" Hospital and stored at $-30{ }^{\circ} \mathrm{C}$ until analysis.

\section{Sample preparation}

A $2 \mathrm{~mL}$ of human whole blood or plasma were shaken for $1 \mathrm{~min}$ and then homogenized thoroughly. To the homogenate were added $80 \mu \mathrm{L}$ of a $5 \mathrm{ng} / \mu \mathrm{L}$ solution of nalorphine (I.S.) and $8 \mathrm{~mL}$ of $100 \mathrm{mM} \mathrm{pH} 6.0$ phosphate buffer. The sample solutions were vortexed for $1 \mathrm{~min}$ and sonicated at room temperature for 1 hour. After centrifugation at 4,000 rpm for $15 \mathrm{~min}$, the supernatants were introduced in the extraction column.

The concentrations of the analytes, were calculated using calibration curves consisting of a spiked human whole blood and plasma samples (the ranges of $20-1500 \mathrm{ng} / \mathrm{mL}$ for morphine, 6-MAM, heroin, and fentanyl; and of $20-3000 \mathrm{ng} / \mathrm{mL}$ for codeine and methadone). Linear regression lines were obtained by plotting the peak area ratios (the compound peak area divided by the internal standard)

\section{Solid-phase extraction (SPE)}

The solid-phase extraction was performed using a Bond Elut Certify column. The solid-phase extraction cartridges were preconditioned with $3 \mathrm{~mL}$ of methanol, $3 \mathrm{~mL}$ of water, and $100 \mathrm{mM} \mathrm{pH} 6.0$ phosphate buffer, all under vacuum (no more than $3 \mathrm{~mm} \mathrm{Hg}$ ). The prepared samples were then applied and allowed to pass through the column at a rate of 1 to $1.5 \mathrm{~mL} / \mathrm{min}$. The sorbent was washed with $3 \mathrm{~mL}$ of water, $3 \mathrm{~mL}$ of $0.1 \mathrm{M} \mathrm{pH} 4.0$ acetate buffer, and $3 \mathrm{~mL}$ of methanol. The vacuum was maintained at $15 \mathrm{~mm} \mathrm{Hg}$ for $5 \mathrm{~min}$ to dry the column completely. Finally, the opiods were eluted with $3 \mathrm{~mL}$ of dichloromethane-isopropanol-ammonia $(78: 20: 2 \mathrm{v} / \mathrm{v} / \mathrm{v})$ into amber collection tubes. The solvent was evaporated under a gentle stream of nitrogen and the residue was derivatized with $50 \mu \mathrm{L}$ of Bis(trimethylsilyl)trifluoroacetamide:tr imethylchlorosilane (99:1) and $50 \mu \mathrm{L}$ of ethyl acetate for 25 minutes at $70^{\circ} \mathrm{C}$.

\section{GC-MS}

Chromatographic analysis was carried out on an Agilent Series 6890N system (Agilent, USA- Weisser Analytical) equipped with an Automatic Sampler 7683 series linked with injector programmed temperature volatilization (PTV) and DB-5MS capillary columns $(50 \mathrm{~m} \times 0.22 \mathrm{~mm}, 0.33 \mu \mathrm{m}$ film thickness). The injection volume was $5 \mathrm{~mL}$ in solvent vent mode. Selective mass detector together with a Chemstation software suite (Agilent, USAWeisser Analytical) version A.09 was used for data processing and instrument control. The temperature of the PTV injector in solvent vent mode was set at $100^{\circ} \mathrm{C}$ and the flow rate was kept at $2 \mathrm{~mL} / \mathrm{min}$ using helium as carrier gas. The oven temperature was programmed as follows: the initial temperature was set 
at $50{ }^{\circ} \mathrm{C}$, held for $1.30 \mathrm{~min}$, and ramped at $7{ }^{\circ} \mathrm{C} / \mathrm{min}$ to $220^{\circ} \mathrm{C}$, where it was held for $1.45 \mathrm{~min}$ and again ramped at $7{ }^{\circ} \mathrm{C} / \mathrm{min}$ to $330^{\circ} \mathrm{C}$ and held for $17 \mathrm{~min}$.

The GC-MS analysis for identification of opiods were carried out in gas chromatography equipped with an Agilent 5975 mass selective detector operated in electron impact mode (Agilent USA- Weisser Analytical). The temperatures of the quadrupole, ion source and mass selective detector interface were 150,230 and $300{ }^{\circ} \mathrm{C}$, respectively.

\section{RESULTS AND DISCUSSION}

We present a validated analytical procedure for the simultaneous quantification of morphine, 6-MAM, codeine, heroin, fentanyl and methadone in human whole blood and plasma. Optimization of this method was first carried out using nalorphine as internal standard and then progressed to using blank human whole blood and plasma samples spiked with each of the six opioids The development and validation of an analytical method that can quantify exposure to multiple drug classes and metabolites offers several advantages, including the cost of reagents, supplies and labor. Furthermore, savings are achieved in the required numbers of expensive instruments and capillary columns and other consumables that might be required for analysis and in the time needed to change equipment between different analytical assays. In addition, multiple data are produced in the most time efficient manner. The most important advantage is the ability to maximize information in cases with limited specimen availability. ${ }^{19}$

The most common biological samples used for the screening of drugs are serum/ plasma, blood and urine. ${ }^{23}$ Blood, plasma and serum can often be interchanged in most methods although human whole blood needs to be deproteinised when submitted to solid-phase extraction, while plasma not need treatment.

The solid phase extraction has some merits for sample preparation; our group confirmed the usefulness of the Bond Elut Certify columns for extraction of abused drugs from biological fluids. ${ }^{22}$

Tables 1 and 2 show the linearity, relative standard deviation, limit of detection (LOD), and limit of quantitation (LOQ), in human whole blood and plasma (mass selective detector). Linearity was assessed using the optimized conditions using an internal standard. When using the internal standard, concentrations in human whole blood and plasma ranged of $20-1500 \mathrm{ng} /$ $\mathrm{mL}$ for morphine, 6-MAM, heroin and fentanyl; and of $20-3000 \mathrm{ng} / \mathrm{mL}$ for codeine and methadone. Correlation coefficients were $r^{2}>0.994$ for human whole blood and $\mathrm{r}^{2}>0.996$ for plasma obtained for each opioid compounds. The ranges of linearity of the opiods studied were satisfactory with respect to the subtherapeutic and toxic range for forensic and clinical purposes.

Table 1. Linearity, relative standard deviation (RSD), limit of detection (LOD), and limit of quantitation (LOQ), in human whole blood. (mass selective detector).

\begin{tabular}{|l|c|c|c|c|c|}
\hline Compound & $\begin{array}{c}\text { Tested } \\
\text { range } \\
\left(\mathrm{ng} \mathrm{mL}^{-1}\right)\end{array}$ & $\left(\mathrm{r}^{2}\right)^{\mathrm{a}}$ & $\mathrm{RSD}$ & $\begin{array}{c}\text { LOD } \\
(\mathrm{ng} \\
\left.\mathrm{mL}^{-1}\right)\end{array}$ & $\begin{array}{c}\text { LOQ } \\
\left(\mathrm{ng} \mathrm{mL}^{-1}\right)\end{array}$ \\
\hline Morphine & $20-1500$ & 0.9991 & 1.74 & 3.46 & 10.50 \\
\hline 6-MAM & $20-1500$ & 0.9947 & 1.78 & 7.63 & 23.13 \\
\hline Heroin & $20-1500$ & 0.9981 & 1.50 & 0.40 & 1.30 \\
\hline Fentanyl & $20-1500$ & 0.9985 & 8.55 & 4.62 & 14.00 \\
\hline Codeine & $20-3000$ & 0.9986 & 5.61 & 6.70 & 20.30 \\
\hline Methadone & $20-3000$ & 0.9953 & 6.37 & 6.50 & 19.83 \\
\hline
\end{tabular}

a $\mathrm{r}^{2}=$ Square of correlation coefficient with a weighting factor of $1 /$ concentration.

The limits of detection were calculated based on the standard deviation (SD) of the response and the slope (S) of the calibration curve(s) at levels approximating the LOD according to the formula: $\mathrm{LOD}=3.3(\mathrm{SD} / \mathrm{S})$; the $\mathrm{LOD}$ for each analyte varied between 0.40 and $7.63 \mathrm{ng} / \mathrm{mL}$ in whole blood and 0.80 and $32.00 \mathrm{ng} / \mathrm{mL}$ in plasma.
Table 2. Linearity, relative standard deviation (RSD), limit of detection (LOD), and limit of quantitation (LOQ) in human plasma. (mass selective detector)

\begin{tabular}{|l|c|c|c|c|c|}
\hline Compound & $\begin{array}{c}\text { Tested range } \\
(\mathrm{ng} \mathrm{mL})^{-1}\end{array}$ & $\left(\mathrm{r}^{2}\right)^{\mathrm{a}}$ & RSD & $\begin{array}{c}\text { LOD } \\
\left(\mathrm{ng} \mathrm{mL}^{-1}\right)\end{array}$ & $\begin{array}{c}\mathrm{LOQ} \\
\left(\mathrm{ng} \mathrm{mL}^{-1}\right)\end{array}$ \\
\hline Morphine & $20-1500$ & 0.9993 & 2.07 & 3.30 & 10.20 \\
\hline 6-MAM & $20-1500$ & 0.9995 & 0.68 & 32.00 & 97.00 \\
\hline Heroin & $20-1500$ & 0.9995 & 7.42 & 2.30 & 7.00 \\
\hline Fentanyl & $20-1500$ & 0.9966 & 8.36 & 8.70 & 26.50 \\
\hline Codeine & $20-3000$ & 0.9992 & 6.21 & 14.70 & 44.60 \\
\hline Methadone & $20-3000$ & 0.9971 & 1.06 & 0.80 & 2.60 \\
\hline
\end{tabular}
concentration.

The limit of quantitation is the lowest concentration that can be measured on the standard curves with acceptable reproducibility. The LOQs determined for the six opiods tested allowed the measurement of subtherapeutic and toxic concentrations of these compounds.

The solid phase extractions were determined in triplicate at three concentrations (low, medium and high) of each opiods in human whole blood and plasma.The solid-phase extraction efficiency of the opiods in the $20-1500 \mathrm{ng} / \mathrm{mL}$ and $20-3000 \mathrm{ng} / \mathrm{mL}$ range were more than $86 \%$ and $77 \%$ in human whole blood and more than $91 \%$ in plasma as shown in Table 3. Average recoveries were $89.8 \%$ for whole blood and $94.1 \%$ for plasma. These results suggested that there was no relevant difference in extraction recovery at different concentration levels in human whole blood and plasma for the analytes under investigations.

This work showed the high sensitivity of our method using GC/MS with various chromatographic methods published in the literature. ${ }^{11-21}$ According to the LODs from the literature shown in Table 4, our assay using the described Bond Elut Certify method of choice allows the detection and quantification of 6-MAM, morphine, codeine, fentanyl, heroin, and methadone in human whole blood and plasma at subtherapeutic and toxic levels. In equal matrices we have obtained similar LODs. ${ }^{11,16}$ Other matrices are difficult to compare and are of little use in the Laboratorio Referencial Norte, Servicio Medico Legal, IquiqueChile.

Table 5 shows the results obtained for intra-assay and inter-assay precision calculations and selected ions used for qualification and quantification of all the analytes. Inter-day and intra-day precision were $<10 \%$ and $<6.5 \%$ for all analytes. Precision of the analytes under investigation at reported concentrations met satisfactorily the internationally established acceptance criteria. ${ }^{14}$

A representative chromatogram obtained by GC/MS following the extraction of morphine, 6-MAM, codeine, heroin, fentanyl, methadone, and nalorphine (internal standard) is shown in Fig. 2. Using this method, all of the analytes of interest were resolved in $16 \mathrm{~min}$. The retention time for each analyte was: methadone, $12.48 \mathrm{~min}$; codeine, $14.00 \mathrm{~min}$; morphine, $14.20 \mathrm{~min}$; 6-MAM, $14.72 \mathrm{~min}$; heroin, $14.38 \mathrm{~min}$ and fentanyl, $16.10 \mathrm{~min}$. The internal standard, nalorphine, gave a retention time of $14.95 \mathrm{~min}$. There is a paucity of data in the literature concerning fentanyl concentration in human whole blood and plasma following heroin use, since most laboratories only monitors the presence of morphine, codeine, and occasionally 6-MAM.

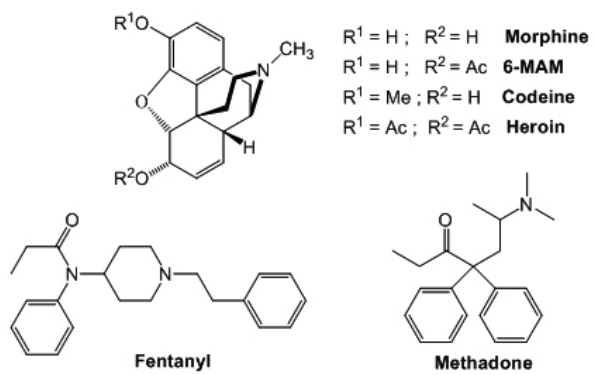

Figure 1. Structures of the six opiods studied: morphine, 6-MAM, codeine, heroin, fentanyl, and methadone. 


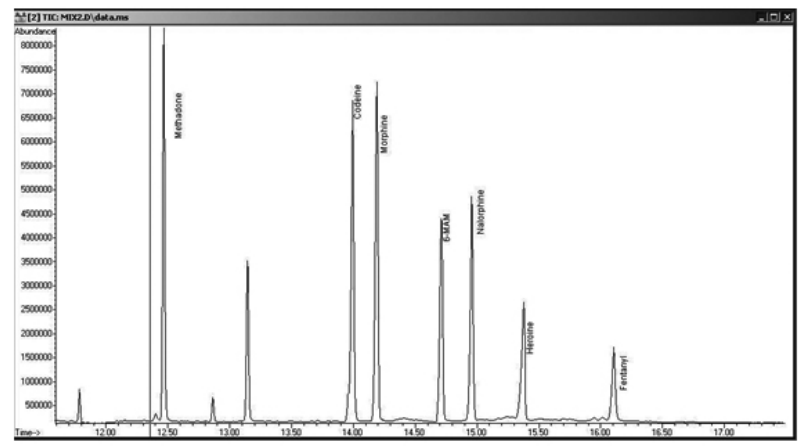

Figure 2. Total ion chromatogram of the six opiods: morphine, 6-MAM, codeine, heroin, fentanyl, and methadone.

Table 3. Solid-phase extraction efficiency in human whole blood and plasma.

\begin{tabular}{|l|c|c|c|c|c|c|c|c|}
\hline \multirow{2}{*}{ Compound } & \multicolumn{4}{|c|}{$\begin{array}{c}\text { Whole Blood SPE } \\
\text { efficiency (\%) }\end{array}$} & \multicolumn{4}{c|}{$\begin{array}{c}\text { Plasma SPE } \\
\text { efficiency (\%) }\end{array}$} \\
\cline { 2 - 11 } & Low* & Medium* & High* & RSD & Low* & Medium* & High* & RSD \\
\hline Morphine & 94.2 & 93.2 & 87.8 & 3.75 & 93.2 & 102.1 & 98.9 & 4.60 \\
\hline 6-MAM & 91.2 & 101.1 & 101.3 & 5.90 & 92.0 & 93.9 & 91.2 & 1.50 \\
\hline Heroin & 90.7 & 90.5 & 93.3 & 1.71 & 93.9 & 100.2 & 94.5 & 3.79 \\
\hline Fentanyl & 87.2 & 86.7 & 84.4 & 1.73 & 91.8 & 93.5 & 90.0 & 1.82 \\
\hline Codeine & 92.8 & 91.5 & 98.7 & 4.07 & 93.8 & 95.5 & 93.7 & 1.07 \\
\hline Methadone & 77.5 & 76.9 & 77.5 & 0.45 & 91.1 & 93.7 & 90.5 & 1.85 \\
\hline Nalorphine & nd & 91.2 & nd & 0.33 & nd & 96.1 & nd & 0.90 \\
\hline
\end{tabular}

$\mathrm{RSD}=$ relative standar deviation

$* n=3$

nd $=$ Not determined

Table 4. Limit of detection (LOD) of opiods studied by various chromatographic methods published in the literature in the last ten years.

\begin{tabular}{|c|c|c|c|c|}
\hline Opiods & Matrix & Detection & LOD & Reference \\
\hline $\begin{array}{l}\text { Morphine } \\
\text { 6-MAM } \\
\text { Heroin } \\
\text { Fentanyl } \\
\text { Codeine } \\
\text { Methadone }\end{array}$ & $\begin{array}{l}\text { Whole } \\
\text { Blood }\end{array}$ & LC-MS/MS & $\begin{array}{c}7.0 \mathrm{ng} / \mathrm{mL} \\
2.0 \mathrm{ng} / \mathrm{mL} \\
2.0 \mathrm{ng} / \mathrm{mL} \\
0.08 \mathrm{ng} / \mathrm{mL} \\
3.0 \mathrm{ng} / \mathrm{mL} \\
0.07 \mathrm{ng} / \mathrm{mL}\end{array}$ & 11 \\
\hline $\begin{array}{l}\text { Morphine } \\
\text { Codeine }\end{array}$ & Oral fluids & $\mathrm{LC} / \mathrm{MS}$ & $\begin{array}{l}0.22 \mathrm{ng} / \mathrm{mL} \\
0.30 \mathrm{ng} / \mathrm{mL}\end{array}$ & 12 \\
\hline $\begin{array}{l}\text { Morphine } \\
\text { 6-MAM } \\
\text { Codeine }\end{array}$ & Urine & $\begin{array}{c}\text { UPLC-MS/ } \\
\text { MS }\end{array}$ & $\begin{array}{l}2.6 \mathrm{ng} / \mathrm{mL} \\
1.0 \mathrm{ng} / \mathrm{mL} \\
2.2 \mathrm{ng} / \mathrm{mL}\end{array}$ & 13 \\
\hline $\begin{array}{l}\text { Morphine } \\
\text { 6-MAM } \\
\text { Codeine }\end{array}$ & Meconium & LC/MS & $\begin{array}{l}1.2 \mathrm{ng} / \mathrm{mL} \\
0.3 \mathrm{ng} / \mathrm{mL} \\
1.2 \mathrm{ng} / \mathrm{mL}\end{array}$ & 14 \\
\hline Methadone & Meconium & $\begin{array}{l}\text { LC-APCI- } \\
\text { MS/MS }\end{array}$ & $1.0 \mathrm{ng} / \mathrm{g}$ & 15 \\
\hline Methadone & Plasma & LC/MS & $5.0 \mathrm{ng} / \mathrm{mL}$ & 16 \\
\hline Morphine & Hair & GC/MS & $0.016 \mathrm{ng} / \mathrm{mg}$ & 17 \\
\hline $\begin{array}{l}\text { Morphine } \\
\text { 6-MAM } \\
\text { Codeine }\end{array}$ & Hair & GC/MS & $\begin{array}{l}5.0 \mathrm{ng} / \mathrm{mg} \\
5.0 \mathrm{ng} / \mathrm{mg} \\
2.0 \mathrm{ng} / \mathrm{mg}\end{array}$ & 18 \\
\hline $\begin{array}{l}\text { Morphine } \\
\text { 6-MAM } \\
\text { Codeine }\end{array}$ & Skin & GC/MS & $\begin{array}{l}2.5 \mathrm{ng} / \text { biopsy } \\
2.5 \mathrm{ng} / \mathrm{biopsy} \\
2.5 \mathrm{ng} / \mathrm{biopsy}\end{array}$ & 19 \\
\hline $\begin{array}{l}\text { Morphine } \\
\text { 6-MAM } \\
\text { Heroin } \\
\text { Codeine } \\
\text { Methadone }\end{array}$ & Sweat & GC/MS & $\begin{array}{l}1.25 \mathrm{ng} / \text { patch } \\
2.5 \mathrm{ng} / \mathrm{patch} \\
2.5 \mathrm{ng} / \mathrm{patch} \\
1.25 \mathrm{ng} / \mathrm{patch} \\
5.0 \mathrm{ng} / \text { patch }\end{array}$ & 20 \\
\hline Morphine & Placenta & GC/MS & $2.4 \mathrm{ng} / \mathrm{mL}$ & 21 \\
\hline
\end{tabular}

Table 5. Intra- and inter-day precision, and selected ions for opiods.

\begin{tabular}{|c|c|c|c|}
\hline \multirow{2}{*}{ Compound } & $\begin{array}{c}\text { Inter-day } \\
\text { precision* }\end{array}$ & $\begin{array}{c}\text { Intra-day } \\
\text { precision* }\end{array}$ & \multirow{2}{*}{$\begin{array}{c}\text { Selected ions } \\
(\mathrm{m} / \mathrm{z})\end{array}$} \\
\cline { 2 - 3 } & RSD (\%) & RSD (\%) & \\
\hline Morphine & 8.28 & 2.42 & $\underline{\mathbf{7 3}}, 429,236,146$ \\
\hline 6-MAM & 9.84 & 0.63 & $73, \underline{\mathbf{3 9 9}}, 340,287$ \\
\hline Heroin & 4.41 & 1.89 & $\underline{\underline{327}, 369,268,310}$ \\
\hline Fentanyl & 9.48 & 0.87 & $\underline{\mathbf{2 4 5}}, 189,146$ \\
\hline Codeine & 6.82 & 5.16 & $\underline{\mathbf{7 3}}, 371,178,196$ \\
\hline Methadone & 8.33 & 6.42 & $\underline{\mathbf{7 2}}, 309,294$ \\
\hline
\end{tabular}

$*_{\mathrm{n}}=10$

The underlined ions were used for quantitation.

\section{CONCLUSION}

The present study shows that this GC/MS method was applicable to the simultaneous analysis of six opioids, namely morphine, 6-MAM, codeine, heroin, fentanyl, and methadone in human whole blood and plasma samples. The main advantage of this method over earlier methods is the rapid, selectively, sensitive and simple extraction procedure and GC/MS analysis for the simultaneous measurement of several opioid drugs most frequently used medically, as well as the potent heroin of illegal use. Identification reliability was achieved by monitoring fragment ions and using relative retention time. The current method is being applied in the forensic analyses of the Laboratorio Referencial Norte, Servicio Medico Legal, Iquique-Chile.

\section{ACKNOWLEDGEMENTS}

We thank Laboratorio Referencial Norte, Servicio Medico Legal, Iquique and Universidad Arturo Prat for financial support of this study. 


\section{REFERENCES}

1. European Monitoring Centre for Drugs and Drug Addiction (EMCDDA). The state of the drug problem in the European Union and Norway. Annual Report 2009.Lisbon: EMCDDA; 2009. Available at http://www.emcdda. europa.eu/publications/annualreport/2009.

2. M. Arendt, P. Munk-Jørgensen, L. Sher, S. O.W. Jensen. Drug and Alcohol Dependence doi:10.1016/j.drugalcdep.2010.09.013, (2010).

3. United Nations Office on Drugs and Crime, 2008. World Drug Report 2008. Vienna, United Nations.

4. L. Degenhardt, D. Randall, W. Hall, M. Law, T. Butler, L. Burns. Drug and Alcohol Dependence 105, 9-15, (2009).

5. L. Degenhardt, W. Hall, M. Lynskey, M. Warner-Smith. (2004). Chapter 13 Illicit drug use. In: Ezzati, M., Lopez, A.D., Rodgers, A.,Murray, R. (Eds.), Comparative Quantification of Health Risks: Global and Regional Burden of Disease Attributable to Selected Major Risk Factors, vol. 2. World Health Organization, Geneva, pp. 1109-1176.

6. S. Darke, L. Degenhardt, R.P. Mattick, (Eds.), 2006. Mortality Amongst Illicit Drug Users. Cambridge University Press, Cambridge.

7. W. F. M. Van Bever, C. J. E. Niemegeers, P. A. J. Janssen. Journal Medicinal Chemistry 17, 1047-1051, (1974).

8. J. Højsted, P. Sjøgren. European Journal of Pain 11, 490-518, (2007).

9. W. M. Walwyna, K. A. Miotto, C. J. Evans. Drug and Alcohol Dependence 108, 156-165, (2010).

10. M. Neira-León, G. Barrio, M. J. Bravo, M. T. Brugal, L. de la Fuente, A. Domingo-Salvany, J. Pulido, S. Santos. International Journal of Drug Policy 22, 16-25 (2011)

11. M. Gergov, P. Nokua, E. Vuori, I. Ojanpera. Forensic Science International 186, 36-43, (2009).
12. K. A. Mortier, K. E. Maudens, W. E. Lambert, K. M. Clauwaert, J. F. Van Bocxlaer, D. L. Deforce, C. H. Van Peteghem, A. P. De Leenheer. Journal of Chromatography B 779, 321-330, (2002).

13. T. Berg, E. Lundanes, A. S. Christophersen, D. H. Strand. Journal of Chromatography B 877, 421-432, (2009).

14. S. Pichini, R. Pacifici, M. Pellegrini, E. Marchei, E. Pérez-Alarcón, C. Puig, O. Vall, O. García-Algar. Journal of Chromatography B 794, $281-$ 292, (2003).

15. R. E. Choo, C. M. Murphy, H. E. Jones, M. A. Huestis. Journal of Chromatography B 814, 369-373, (2005).

16. H. R. Liang, R.L. Foltz, M. Meng, P. Bennett. Journal of Chromatography $B$ 806, 191-198, (2004).

17. O. Sabzevari, Kh. Abdi, M. Amini, A. Shafiee. Analytical and Bioanalytical Chemistry 379, 120-124, (2004).

18. M. Moller, K. Aleksa, P. Walasek, T. Karaskov, G. Koren. Forensic Science International 196, 64-69, (2010).

19. W. Yang, A. J. Barnes, M. G. Ripple, D. R. Fowler, E. J. Cone, E. T. Moolchan, H. Chung, M. A. Huestis. Journal of Chromatography B 833, 210-218, (2006).

20. B. R. Brunet, A. J. Barnes, K. B. Scheidweiler, P. Mura, M. A. Huestis. Analytical and Bioanalytical Chemistry 392, 115-127, (2008).

21. X. Joya, M. Pujadas, M. Falcón, E. Civit, O. Garcia-Algar, O. Vall, S.Pichini, A. Luna, R. de la Torre. Forensic Science International 196, 38-42, (2010).

22. F. Bravo, C. Lobos, K. Venegas, J. Benites. Journal of Chilean Chemical Society 55, 454 - 457, (2010).

23. O. H. Drummer. Journal of Chromatography B 733, 27-45, (1999). 